\title{
Epigean and subterranean ichthyofauna in Cordisburgo karst area, eastern Brazil
}

\author{
Eleonora Trajano ${ }^{1,2}$, Sandro Secutti ${ }^{1}$ \& George Mendes Taliaferro Mattox ${ }^{1}$ \\ ${ }^{1}$ Departamento de Zoologia, Instituto de Biociências da USP, \\ CP 11461, CEP 05422-970, São Paulo, SP, Brasil \\ ${ }^{2}$ Corresponding author: Eleonora Trajano,e-mail: etrajano@usp.br
}

TRAJANO, E., SECUTTI, S. \& MATTOX, G.M.T. Epigean and subterranean ichthyofauna in Cordisburgo karst area, eastern Brazil. Biota Neotrop. 9(3): http://www.biotaneotropica.org.br/v9n3/en/abstract?inventor $\mathrm{y}+\mathrm{bn} 02109032009$.

\begin{abstract}
After an ichthyofaunistic survey conducted in May 2007 on surface (epigean) water bodies of Cordisburgo karst area, State of Minas Gerais, 13 species were recorded, mostly characiforms; in addition three non-troglomorphic (normally eyed and pigmented) and one troglomorphic catfish (siluriforms) species were recorded in two caves surveyed at different occasions, totaling 17 fish species for the area. All the nominal species herein reported for Cordisburgo area have been previously reported for the Rio das Velhas basin. None of the species observed in caves were found in epigean habitats and vice-versa. The four cave species are distributed throughout subterranean stream reaches, with individuals at different size/age classes. This, associated to the lack of conspicuous morphological differences in relation to epigean congeners, indicate that Trichomycterus brasiliensis, Gymnotus cf. carapo and Pimelodella cf. vittata are troglophiles (species encompassing individuals able to live and complete their life cycle either in the surface or in the subterranean environment) in the Morena Cave; the latter forms a large population and may be at the beginning of a differentiation process due to isolation in the subterranean habitat, as indicated by a slight reduction in eye size. Topographic isolation may be the cause for the incipient, but unmistakable troglomorphism of the Rhamdiopsis population found in the Salitre Cave, allowing for its classification as troglobite (exclusively subterranean species). The Cordisburgo area is subject to significant anthropic pressure, mainly represented by deforestation for agriculture, cattle raising and timbering. Tourism is an additional important threat for cave communities, calling for urgent protection measures.
\end{abstract}

Keywords: Minas Gerais State, caves, troglobites, troglophiles, freswater fishes, biodiversity.

TRAJANO, E., SECUTTI, S. \& MATTOX, G.M.T. Ictiofauna epígea e subterrânea na área cárstica de Cordisburgo, Estado de Minas Gerais. Biota Neotrop. 9(3): http://www.biotaneotropica.org.br/v9n3/pt/abstr act?inventory+bn02109032009.

Resumo: Um levantamento ictiofaunístico em corpos d'água epígeos (superficiais) da área cárstica de Cordisburgo, Minas Gerais, realizado em maio de 2007, resultou no registro de 13 espécies, a maioria Characiformes; adicionalmente, três espécies não-troglomórficas e uma troglomórfica (com olhos e pigmentação reduzidos em comparação aos congêneres epígeos) de bagres foram encontradas em duas cavernas visitadas em diversas ocasiões, totalizando 17 espécies de peixes para a região. Todas as espécies nominais aqui registradas para Cordisburgo haviam sido reportadas anteriormente para a bacia do Rio das Velhas. Nenhuma das espécies amostradas nas localidades epígeas foi observada nas cavernas e vice-e-versa. As quatro espécies subterrâneas ocorrem ao longo de riachos subterrâneos, sendo observados indivíduos de diferentes faixas de tamanho/etárias. Isto, associado à ausência de diferenças morfológicas notáveis em relação a coespecíficos de localidades epígeas, indicam que Trichomycterus brasiliensis, Gymnotus cf. carapo e Pimelodella cf. vittata são troglófilos (espécies com indivíduos capazes de viver e completar o ciclo de vida tanto no ambiente superficial como no subterrâneo) na Gruta Morena; esta última pode estar no início de processo de diferenciação devido ao isolamento, pelo menos parcial, na caverna, conforme sugerido pela ligeira redução no tamanho dos olhos. Tal isolamento pode ser igualmente a causa do troglomorfismo incipiente, porém indubitável, dos bagres Rhamdiopsis da Gruta do Salitre, permitindo sua classificação como troglóbios (espécie exclusivamente subterrânea). A região de Cordisburgo há muito vem sendo sujeita a pressão antrópica significativa, representada principalmente pelo desmatamento para agricultura, pastagem e extração de madeira. Turismo é uma ameaça adicional para as populações cavernícolas, sendo urgentes medidas para sua proteção.

Palavras-chave: Minas Gerais, cavernas, troglóbios, troglófilos, peixes de água doce, biodiversidade. 


\section{Introduction}

Rio das Velhas is one of the main tributaries on the right bank of the upper Rio São Francisco, having part of its headwaters located on the Serra do Cipó and Serra do Espinhaço, Minas Gerais State. The drainage occupies an area of $29.173 \mathrm{~km}^{2}$ and constitutes one of the UPGRH (Unidade de Planejamento e Gestão dos Recursos Hídricos - Water Resources Management Unit) in the State of Minas Gerais (Camargos, 2005). This region has great social and economic importance because it harbors a population of almost 4.5 million people, receiving water from the Quadrilatero Ferrífero region as well as the State capital, Belo Horizonte (IBGE 2000). Some parts of the drainage are located in karst areas, as is the case of the region around the town of Cordisburgo.

The ichthyofauna of the Rio das Velhas drainage began to be studied in the late XVIII and early XIX centuries with the discovery of new species based on collections made by Auguste Saint-Hilaire, Johan von Spix, Karl von Martius, Francis Castelnau and Ch. Cumberland (Britski 2001). The first synthesis of the knowledge on these fishes was the classic study published by Lütken in 1875 (Lütken 2001), who cited 55 species for the Rio das Velhas basin. This figure increased to 93 in the recent work by Alves \& Pompeu (2001). This represents around $50 \%$ of the total number of fish species recorded in the Rio São Francisco basin (Britski et al. 1984, Sato \& Godinho 1999, Alves \& Pompeu 2001, Costa 2002).

So far, 24 species of Brazilian subterranean fishes are known to present the classical troglomorphisms related to the hypogean life, i.e., reduction of eyes and/or pigmentation at least at some degree beyond that observed in their epigean (surface) congeners, indicating a troglobitic (exclusively subterranean) status. In addition, several nontroglomorphic fishes have also been recorded in caves, being either troglophilic (species able to establish self-sustained populations both in epigean and in subterranean habitats), trogloxenic (found in both epigean and subterranean habitats, but each individual must return periodically to the surface in order to complete its life cycle) or accidentals (Mattox et al. 2008). These species are found in caves and other subterranean habitats throughout Brazil, with six occurring in the upper São Francisco River basin, including one presently reported for the Cordisburgo region.

\section{Study area}

The Cordisburgo karst area is located in the State of Minas Gerais (MG), Rio das Velhas basin, upper Rio São Francisco basin. It is situated within the Cerrado (savannah-like) Domain (sensu Ab'Saber 1977), but most of the original vegetation has long been removed for pasture and agriculture, including extensive Eucaliptus areas. The proximity to important urban centers (Belo Horizonte, the State capital, is approximately $100 \mathrm{~km}$ in straight line) and location in a historically exploited region (limestone mining, timbering, agriculture, cattle raising) and pathway for travelers in the past centuries result in a moderate to high level of environmental disturbance. Partially preserved vegetation, corresponding to seasonal semi-deciduous forest, is found on the top of hills, karst depressions and valleys. According to Nimer's (1989) classification, the climate in Cordisburgo area is tropical sub-warm semi-humid, with a 4-month dry period, from May to September.

Geologically, the Cordisburgo karst area belongs to the Bambui Group, which comprises horizontally bedded Upper Proterozoic limestones widely distributed throughout Minas Gerais, Bahia and Goiás states. Typically, caves in Cordisburgo area show a dendritic pattern with active drainage. The Morena cave, over $5 \mathrm{~km}$ long, is the largest in the area. The oldest and most intensively visited Brazilian commercial cave, the Gruta do Maquiné, is also located in
Cordisburgo area, only a few kilometers from the town of Cordisburgo (Auler \& Farrant 1996).

Epigean (surface) localities. Three different epigean localities were sampled for fishes in May 2007, and are numbered below. All collection sites were sampled during the daytime and localities 2 (Ribeirão da Onça) and 3 (Cachoeira do João Parriba) were also surveyed after sunset.

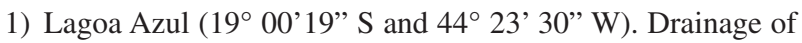
Rio das Velhas, Rio São Francisco basin. Cordisburgo, MG. A nearly elliptical pond, around $30 \times 20$ meters wide. It receives water from a submersed spring. According to local residents, the pond is more than 15 meters deep. Water color is characteriscally tourquoise blue. Two streams ca. 1 meter wide and 0.5 meter deep with sandy and muddy bottom exit the pond. Dense grass and some bushes and trees compose the marginal vegetation of the whole system. Part of the pond shaded by trees.

2) Ribeirão da Onça ( $19^{\circ} 06^{\prime} 45^{\prime \prime} \mathrm{S}$ and $\left.44^{\circ} 19^{\prime} 17^{\prime \prime} \mathrm{W}\right)$. Drainage of Rio das Velhas, Rio São Francisco basin. A small sized river, 4-5 meters wide in average, with water flow varying from fast in shallow areas with rocky bottoms to slow in pools 2-3 meters deep with sandy bottom formed in some curves. Marginal vegetation relatively rich, formed basically by bushes, tree roots and aquatic macrophytes. Some aquatic macrophytes benches were also present in sandy bottom areas of the river.

3) Cachoeira do João Parriba (19 $03^{\circ} 11^{\prime \prime} \mathrm{S}$ and $\left.44^{\circ} 25^{\prime} 09^{\prime \prime} \mathrm{W}\right)$. Drainage of Rio das Velhas, Rio São Francisco basin. Sequence of rocky shelves forming 90 degrees steps varying from 2-3 to more than 10 meters high, covered by a thin water column in most of its surface and pools 2-3 meters deep formed on shelves near waterfalls. Little marginal vegetation present as river is sided by tall rocky walls.

Cave localities. Hypogean streams in three caves were sampled:

4) Salitre Cave (19 $07^{\prime} 17^{\prime \prime} \mathrm{S}$ and $\left.44^{\circ} 28^{\prime} 24^{\prime \prime} \mathrm{W}\right)$, visited on seven occasions, in April, July and September 2005 and 2006, and April 2008. It has $1098 \mathrm{~m}$ of mapped passageways, with one known entrance, situated in the slope of a hill, 30+ $\mathrm{m}$ high in relation to the epigean valley base level. In the cave lower level, there is a small, mostly soft-bottomed stream running in direction to the entrance end. During the dry season, this stream flows only at the distal part of the cave, in a low ceiling conduit mostly inaccessible to humans; downstream, there are a few shallow isolated pools, connected during rains. Vegetal debris accumulates at this low conduit, providing food sources for fish. The base level inside the cave is at least $20 \mathrm{~m}$ high in relation to the epigean base level.

5) Morena Cave (19 $10^{\prime} 09^{\prime \prime} \mathrm{S}$ and $44^{\circ} 19^{\prime} 54^{\prime \prime} \mathrm{W}$ ), visited on five occasions, in April 2005, September 2006, May, July and October 2007. With 5000+ $\mathrm{m}$ of passageways and seven known entrances, it is the largest cave in the region of Belo Horizonte and surroundings, and includes a variety of aquatic and terrestrial habitats. The $2000 \mathrm{~m}$ long base-level (lowest erosional level) cave stream runs in direction to the distal end of the cave, the initially rocky bottom becoming progressively softer and the cave conduit becoming narrower; a huge amount of vegetal debris accumulates downstream in this sector. An upper vadose tributary joins the main stream conduit at its upstream, rocky reach. 


\section{Materials and Methods}

Collections in epigean sites were carried on using hand nets, seines, cast nets, and gill nets of various sizes and small meshes, during a 5-day long field trip in May 2007. Collections in caves were made using hand nets and minnow traps baited with bovine liver. Some Pimelodella individuals were brought alive to the laboratory for behavioral and cytogenetic studies. Although different localities were not accessed with exactly the same methods, effort was made in order to sample all habitats in each location. Fishes were killed by over-anesthesia in a solution of benzocaine, fixed in formalin $4 \%$ and later transferred to ethanol $70 \%$. Specimens were identified to the species level whenever possible and deposited in the ichthyological collection of Museu de Zoologia da Universidade de São Paulo - MZUSP, São Paulo, SP.

The relative frequency of each epigean species was calculated in terms of number of individuals of each species in relation to the total collected, expressed in percentage. The species were then classified into four categories, according to their abundance: rare, less than $1 \%$ of relative abundance; uncommon, $1-7 \%$ of relative abundance; common, $7-20 \%$ of relative abundance; and very common, over $20 \%$ of relative abundance.

Ad libitum naturalistic observations from outside the water were made. A mark-recapture program using subcutaneous visible implant tags was started for Rhamdiopsis sp. in the Salitre cave, but the low number of specimens captured, allied to the fish fragility, hampered its continuity. Therefore, we used visual censuses to access population data, such as fish distribution and density.

\section{Results}

\section{Epigean ichthyofauna}

Collections on surface aquatic environments yielded 812 specimens of 13 species from ten families of fishes. The families represent three orders commonly found in Neotropical waters: Characiformes with ten species, Siluriformes with two species and Gymnotiformes with a single species. The most diverse family was Characidae with five species, followed by Erythrinidae and Loricariidae, each with two species sampled (Table 1).

The only species sampled in the three epigean localities was Astyanax sp., which was also the most frequent species summing more than $50 \%$ of the specimens collected. This was the only species recorded at the Cachoeira do João Parriba (locality 3) and along with Serrapinus heterodon, which constituted over $20 \%$ of the total capture, were the only species classified as very common. Six species occurred in the two other sampled environments (Lagoa Azul and Ribeirão da Onça), although $S$. heterodon had only one specimen sampled from Riacho da Onça while 167 specimens from Lagoa Azul. Seven species were considered uncommon varying from 1-7\% of total capture, being Steindachnerina elegans, Hasemania cf. nana and Characidium sp. the three most abundant despite of each only occurring in a single locality. Four species were considered rare: Parodon hilarii, Hoplias malabaricus, Hoplias sp. and Eigenmannia cf. virescens; with the exception of Hoplias malabaricus, they were all recorded in both localities, Lagoa Azul and Riacho da Onça. The trahira H. malabaricus was collected only in the Lagoa Azul.

As mentioned above, Cachoeira do João Parriba scored only a single species, Astyanax sp., with 44 specimens sampled. Lagoa Azul had 671 specimens sampled from 11 species, being the most abundant and diverse sampled locality. Three of these species were exclusive of this locality, Characidium sp., Hasemania cf. nana and Hoplias malabaricus. Riacho da Onça presented 97 specimens from nine species, two of them exclusive of this locality: Bryconamericus stramineus and Hypostomus sp.

\section{Subterranean ichthyofauna}

A slightly troglomorphic species of Rhamdiopsis, characterized by reduction in eye size (F.A.Bockmann, pers. comm.), was found in the small stream crossing the Salitre Cave. Visual censuses carried out in 2005 in the accessible stream conduit produced the following counts: April $=21$ individuals, population density ca. 0.2 ind. $\mathrm{m}^{-2}$; July $=26$ individuals, density $=0.26$ ind. $\mathrm{m}^{-2}$; September $=15$ individuals, density $=0.3$ ind. $\mathrm{m}^{-2}$. In all visits during 2006, the water was turbid due to recent rains, hampering visual censuses. Further observations, in April 2008, indicate that the population had remained at the levels observed in 2005.

Three fish species were regularly found in the Morena Cave, inhabiting different stream reaches: Trichomycterus catfish seem to be restricted to a small upper, vadose tributary, whereas Pimelodella and Gymnotus specimens are found in sintopy in the base-level stream. Pimelodella catfish were observed in different habitats, from rockybottomed riffles to slow-moving, soft-bottomed pools, but tended to concentrate in stream reaches with moderate current and pebbled bottom. Gymnotus fish prefer pools.

There are two Pimelodella species described for the Rio São Francisco basin, P. laurenti Fowler, 1941, from the lower São Francisco, in Pernambuco State, and $P$. vittata (Lütken 1874), from Rio das Velhas, upper São Francisco (Bockmann \& Guazelli 2003). In addition to the geographic proximity, the species inhabiting the Morena Cave fits the characters states for $P$. vittata in Eigenmann (1917) except for the eye size: "eye 4 in the head,... about equal to the interorbital" against more than 4 in the head, smaller than interorbital in the species from Morena Cave. In view of the poor taxonomic resolution within the genus, which is in urgent need of a general revision (partial revisions are available for some regions such as the coastal rivers in southern and southeastern Brazil - Guazzelli 1997), it is unclear whether the cave population represents a new, undescribed species, or just a geographic variant within $P$. vittata or other epigean species. Unfortunately, no specimen of this genus was collected in the epigean localities, hampering direct comparisons.

A visual census carried out in September 2006, the end of the dry season, when the water level is the lowest and the fish are more exposed, resulted in ca. 200 Pimelodella catfish counted along $1500 \mathrm{~m}$ long stream, from small (3-4 cm long) to very large $(20+\mathrm{cm})$ individuals. Considering a mean stream width around $1.5 \mathrm{~m}$ at this season, the population density is estimated in ca. 0.1 ind. $\mathrm{m}^{-2}$. Maximum densities of $10+$ medium-sized fish $(9-10 \mathrm{~cm})$ per $\mathrm{m}^{-2}$ were recorded. These fish may form non-polarized groups with 10-15 individuals close to each other but not in contact. At the same occasion, 10+ Gymnotus fish were counted. Apparently, both populations remained stable along our study period.

In our first visit to the Morena Cave in April 2005, 16 Trichomycterus specimens, $\max$. size $=12.3 \mathrm{~cm}$ SL, have been collected in the vadose tributary; additional specimens were observed. The number of fish decreased after the collection event and all observed specimens are relatively small.

\section{Discussion}

\section{Epigean ichthyofauna}

All fish species presently sampled in epigean localities were already reported for the Rio das Velhas basin, either by Lütken (2001), Alves \& Pompeu (2001) or both. It is worth mentioning that three of them were collected only recently by the latter authors: Bryconops 
Table 1. Fish species sampled in Cordisburgo karst area, Minas Gerais State, eastern Brazil. Families are presented in systematic order following Reis et al. (2003), species in alphabetical order within each family. Troglomorphic (troglobitic) species highlighted in bold, the troglophilic ones indicated by an asterisk. Localities: Epigean (surface): 1 - Lagoa Azul; 2 - Riacho da Onça; 3 - Cachoeira do João Parriba; Caves: 4 - Salitre; 5 - Morena.

Tabela 1. Espécies de peixes amostradas na área cárstica de Cordisburgo, Minas Gerais. Famílias apresentadas em ordem sistemática de acordo com Reis et al. (2003), espécies em ordem alfabética dentro de cada família. Espécies troglomórficas (troglóbias) destacadas em negrito, as troglofílicas com um asterisco. Localidades: Epígeas (superfície): 1 - Lagoa Azul; 2 - Riacho da Onça; 3 - Cachoeira do João Parriba; Cavernas: 4 - Salitre; 5 - Morena.

\section{Taxon}

\begin{tabular}{ccccc}
\multicolumn{4}{c}{ Locality } \\
\hline & Epigean & & \multicolumn{3}{c}{ Caves } \\
\hline 1 & 2 & 3 & 4 & 5 \\
\hline
\end{tabular}

Order Characiformes

Family Parodontidae: Parodon hilarii

Family Curimatidae: Steindachnerina elegans

Family Crenuchidae: Characidium sp.

Family Characidae: Astyanax bimaculatus

Astyanax sp.

Bryconamericus stramineus

Hasemania cf. nana

Serrapinus heterodon

Family Erythrinidae: Hoplias malabaricus

Hoplias intermedius

$\mathrm{X}$

$\mathrm{X}$

$\mathrm{X}$

$\mathrm{x}$

$\mathrm{x}$

$\mathrm{x}$

$\mathrm{x}$

$\mathrm{x}$

$\mathrm{x} \quad \mathrm{x}$

Order Siluriformes

family Trichomycteridae: Trichomycterus brasiliensis*

Family Loricariidae: Hypostomus sp.

Parotocinclus sp.

Family Heptapteridae: Pimelodella cf. vittata*

Rhamdiopsis sp.**

Order Gymnotiformes:

family Gymnotidae: Gymnotus cf. carapo*

Family Sternopygidae: Eigenmannia cf. virescens

**Referred to as Rhamdiopsis sp. 3 in Mattox et al. (2008).

stramineus, Serrapinus heterodon and Steindachnerina elegans. Nevertheless, some of the species found in Cordisburgo, such as Parodon hilarii, Serrapinus heterodon and Hoplias malabaricus, have been previously sampled only in Rio Cipó, a tributary of the lower Rio das Velhas, or in lower parts of the rio das Velhas itself (Alves \& Pompeu, 2001).

Some taxa sampled in Cordisburgo could not be identified to the species level either because they were represented by rather imature specimens or because of their uncertain taxonomic status. Hoplias intermedius, for instance, is usually referred in the literature as Hoplias lacerdae, supposedly a species from the Rio Ribeira de Iguape introduced in several other Brazilian drainages. However, a recent taxonomic revision of Hoplias indicated that the species from the São Francisco basin is distinct from the form in the Rio Ribeira de Iguape (Oyakawa \& Mattox 2009). Other taxa of uncertain taxonomic identity are Characidium sp., Hypostomus sp. and Parotocinclus sp., which may represent undescribed species.

Although not reported for the Rio das Velhas basin by Alves \& Pompeu (2001), Pimelodella vittata and Trichomycterus brasiliensis, two species found in the Morena Cave during this study, were mentioned to occur in the drainage by Lütken (2001). The latter author also registered another catfish, Rhamdiopsis microcephalus in the basin, which could be related to the Rhamdiopsis species from the Salitre Cave.

\section{Subterranean ichthyofauna}

Based on the population sizes and stability and the occurrence of different age classes, we hypothesize that Pimelodella cf. vittata, and possibly also Gymnotus sp., form troglophilic populations in the Morena Cave. It is noteworthy that the population density of Pimelodella in the Morena cave is one of the higher, or even the highest observed for troglophilic fish in Brazil (Trajano 1991, pers. obs.). The case of Trichomycterus is more complicated, because the observed specimens may belong to a troglophilic population in the Morena Cave or to a sink population, i.e., a population formed by migrants which, if cut off from the source of migrants, eventually becomes extinct (Fong 2004). In any case, the Morena Cave distinguishes by its rich truly subterranean (i.e., non-accidental) ichthyofauna, which may be attributed, at least in part, to the high availability of nutrients provided by the large banks of vegetal debris observed downstream inside the cave.

The maximum size recorded for P. vittata by Bockmann \& Guazelli (2003) is $9.7 \mathrm{~cm}$ Standard Length, whereas many specimens from the Morena Cave are larger than that, most with 9-12 cm SL, a few reaching maximum sizes of ca. $24 \mathrm{~cm}$ SL. Apparently, large sizes cited for Pimelodella catfish correspond to species living in larger rivers, as $P$. breviceps, from the upper Rio Negro basin (max. length $=36 \mathrm{~cm} \mathrm{SL}), P$. cristata, from the Guyanas $(34 \mathrm{~cm} \mathrm{SL})$ and P. megalura, from the upper Rio Paraguay basin (22 cm SL). Size outliers have been found in cavefish populations in Brazil (e.g., 
Rhamdia enfurnada, the great majority of specimens $<16 \mathrm{~cm} \mathrm{SL}$, most 10-13 cm SL, some surpassing $22 \mathrm{~cm} \mathrm{SL}$; Bichuette \& Trajano 2005; Trajano et al., unpubl. data) and abroad (e.g., the troglophilic Chologaster agassizi - Smith \& Welch 1978: 5, "occasionally an individual is found that is strikingly larger than the average adult").

In view of the fact that the cave stream is situated 20-30 $\mathrm{m}$ above the epigean base-level, topographic isolation may be the cause for differentiation resulting in the troglomorphism characteristic of the Rhamdiopsis population in Salitre Cave. Geographic isolation due to disappearance of epigean populations is a possibility for Pimelodella catfish in the Morena cave, explaining its very incipient reduction of eyes.

\section{Conservation}

The relatively protected condition of subterranean habitats may account for the permanence of heptapterids and trichomycterids in caves of the Cordisburgo karst area, such as Morena and Salitre, where they may form considerable populations. In fact, the Morena ichthyofauna represents the first known instance of three coexisting troglophilic fish populations for Brazil (and possibly worldwide), adding scientific interest to this important cave. In spite of its proximity to the Maquiné Cave, located in a protected area, this cave has been extensively visited without any effective control by the environmental organs responsible by the karst protection in Brazil. In fact, remains of used carbide, footprints and trash are occasionally observed throughout the cave. The creation of a conservation unit encompassing the Morena Cave and surroundings, associated with effective protection measures, including delimitation of visiting areas inside the cave and control of tourism, are urgently needed.

So far, there is no indication that the Rhamdiopsis sp. from Salitre cave is threatened, in spite of the occasional visitation which normally does not include the small stream conduit. Nevertheless, the proximity to Maquiné cave and the possibility of intensification of tourist visitation also calls for preventive measures in order to protect this highly endemic, troglobitic species.

\section{Acknowledgements}

We are most grateful to Osvaldo T. Oyakawa and Janice Muriel-Cunha, from the Museu de Zoologia, who carried out the epigean collections and identifications together with GMTM. Thanks are also due to the students and biologists who helped with the fieldwork, especially Ana Luiza Feigol Guil and Vanessa Felice. This study was suported by the Fundação de Amparo à Pesquisa do Estado de São Paulo - FAPESP, Projeto Temático \# 2003/00974-5. ET is partially supported by the Conselho Nacional de Desenvolvimento Científico e Tecnológico - CNPq (fellowship \# 302174/2004-4). GMTM is supported by CNPq (Doctoral Fellowship \# 140141/2006-5). Permission for collections was given by IBAMA (permissions DIFAP/IBAMA $\mathrm{n}^{\circ} 51$ and 151/2006-CGFAU).

\section{References}

AB'SABER, A.N. 1977. Os domínios morfoclimáticos na América do Sul. Primeira aproximação. Geomorfologia. 52:1-22.

ALVES, C.B.M. \& POMPEU, P.S. 2001. Peixes do Rio das Velhas: passado e presente. SEGRAC, Belo Horizonte, 192 p.
AULER, A. \& FARRANT, A.R. 1996. A brief introduction to karst and caves in Brazil. Proc. Univ. Bristol Spelaeol. Soc. 20:187-200.

BICHUETTE, M.E. \& TRAJANO, E. 2005. A new cave species of Rhamdia Bleeker, 1858 (Siluriformes: Heptapteridae) from Serra do Ramalho, northeastern Brazil, with notes on ecology and behavior. Neotrop. Ichthyol. 3(4):587-595.

BOCKMANN, F. \& GUAZZELLI, G.M. 2003. Family Heptapteridae. In Check list of the freshwater fishes of South and Central America. (R.E. Reis, S.O. Kullander \& C.J. Ferraris, Jr.,eds.) EDIPUCRS, Porto Alegre, p. $406-431$.

BRITSKI, H.A. 2001. Sobre a obra Velhas-Flodens Fiske (Peixes do Rio das Velhas). In Peixes do Rio das Velhas: passado e presente (C.B.M. Alves \& P.S. Pompeu, eds.). SEGRAC, Belo Horizonte, p. 15-22.

BRITSKI, H.A., SATO, Y. \& ROSA, A.B.S. 1984. Manual de identificação de peixes da região de Três Marias: com chaves de identificação para os peixes da Bacia do São Francisco. CODEVASF, Brasília, 143 p.

CAMARGOS, L.M.M. 2005. Plano diretor de recursos hídricos da bacia hidrográfica do Rio das Velhas: resumo executivo dezembro 2004. Instituto Mineiro de Gestão das Águas, Belo Horizonte. 228 p.

COSTA, W.J.E.M. 2002. Peixes anuais brasileiros: diversidade e conservação. UFPR, Curitiba, 238p.

EIGENMANN, C.H. 1917. Pimelodella and Typhlobagrus. Mem. Carnegie Mus. 7(4):229-258

FONG, D.W. 2004. Intermittent pools at headwaters of subterranean drainage basins as sampling sites for epikarst fauna. In Proceedings of the Symposium Held (W.K. Jones, D.C. Culver \& J.S. Herman, eds.) Karst Waters Institute, Shepherdstown, p. 114-188.

Instituto Brasileiro de Geografia e Estatística - IBGE. 2000. Sinopse preliminar do senso demográfico. IBGE, Rio de Janeiro, $450 \mathrm{p}$.

LÜTKEN, C.F. 2001. Peixes do Rio das Velhas: Uma contribuição para a Ictiologia do Brasil. In Peixes do Rio das Velhas: passado e presente. (C.B.M. Alves \& P.S. Pompeu, orgs.). SEGRAC, Belo Horizonte, p. $15-22$.

MATTOX, G.M.T., BICHUETTE, M.E., SECUTTI, S. \& TRAJANO, E. 2008. Surface and subterranean ichthyofauna in the Serra do Ramalho karst area, northeastern Brazil, with updated lists of Brazilian troglobitic and troglophilic fishes. Biota Neotrop. 8(4):145-152.

NIMER, E. 1989. Climatologia do Brasil. SUPREN, Rio de Janeiro, 421 p.

OYAKAWA, O.T. \& MATTOX, G.M.T. 2009.Revision of the Neotropical trahiras of the Hoplias lacerdae species-group (Ostariophysi: Characiformes: Erythrinidae) with descriptions of two new species. Neotrop. Ichthyol. 7(2):117-140.

REIS, R.E., KULLANDER, S.O. \& FERRARIS Jr., C.J. 2003. Check list of the freshwater fishes of South and Central America. EDIPUCRS, Porto Alegre. $735 \mathrm{p}$.

SATO, Y. \& GODINHO, H.P. 1999. Peixes da bacia do Rio São Francisco. In Estudos ecológicos de comunidades de peixes tropicais. (R.H. LoweMcConnel, ed.). Edusp, São Paulo, p. 401-413.

SMITH, P.W. \& WELCH, N.M. 1978. A summary of the life history and distribution of the spring cavefish, Chologaster agassizi Putnam, with population estimates for the species in southern Illinois. Illinois Nat. Hist. Survey. 104:1-8.

TRAJANO, E. 1991. Populational ecology of Pimelodella kronei, troglobitic catfish from southeastern Brazil (Siluriformes, Pimelodidae). Environm. Biol. Fish. 30:407-421. 